KS. WALDEMAR W. ŻUREK SDB* - LUBLIN

\title{
INWENTARZ KOŚCIOLA I PLEBANII W KOSOWIE W 1751 ROKU
}

Początki miasteczka Kosów (Kossów Polski) położonego na kresach województwa brzeskiego sięgają początku XVI wieku. Przed 1520 rokiem wojewoda trocki Jerzy Sapieha ufundował tu kościół parafialny pw. Świętej Trójcy i Świętego Krzyża. Parafia posiadała patronat szlachecki. W 1620 roku kolejny właściciel Kosowa - Leon Sapieha herbu Lis, hetman wielki litewski poszerzył w 1626 roku fundację na rzecz parafii. W 1872 roku podczas pożaru miasta spłonął drewniany kościół, a na jego miejscu w 1878 roku zbudowano w centrum miasta kościół murowany. Parafia rzymskokatolicka liczyła wówczas 1.500 wiernych i należała do dekanatu słonimskiego diecezji wileńskiej, w województwie nowogródzkim. Od 1795 roku Kosów znalazł się w zaborze rosyjskim. Powrócił do Polski po odzyskaniu przez nasz kraj niepodległości. W Kosowie mieściła się siedziba powiatu utworzonego w grudniu 1920 roku, a od lutego następnego roku wszedł do nowo utworzonego województwa poleskiego. W kwietniu 1935 roku powiat kosowski został zniesiony, a z jego terytorium utworzono powiat iwacewicki. W latach międzywojennych parafia kosowska należała do diecezji pińskiej, utworzonej w 1925 roku. Po drugiej wojnie światowej Kosów pozostał w granicach Związku Sowieckiego - w Białoruskiej Socjalistycznej Republice Radzieckiej. Od 1991 roku Kosów leży w granicach Białorusi, w obwodzie brzeskim, rejon Iwacewicze. Kościół zarówno w czasie drugiej wojny światowej, jak i w czasach komunistycznych był nieprzerwanie czynny. Parafia prowadzona przez misjonarzy św. Wincentego a Paulo, należy do dekanatu Prużana, w diecezji pińskiej.

* Ks. Waldemar Witold Żurek SDB - dr hab. historii Kościoła, profesor KUL, dyrektor Ośrodka Archiwów Bibliotek i Muzeów Kościelnych KUL, e-mail: zurek@kul.pl 
Opis fizyczny dokumentu: Inwentarz kościoła i plebanii w Kossowie-1751 r. Decretum Reformationis par. Kossów - 1756 (od ks. K. Świątka), pochodzący z Archiwum Diecezjalnego w Drohiczynie, Zespół Parafia w Kosowie (sygn. III/I/1), jest szczegółową ewidencją stanu kościoła i plebanii, sporządzoną przez księdza Krzysztofa Modzelewskiego 19 stycznia 1751 roku.

Rękopis o wymiarach: $364 \times 213 \mathrm{~mm}$ ma formę składki - pięciu kart zszytych ze sobą w miejscu złożenia lnianymi nićmi; wraz z dodatkowo doklejoną kartą dziesiątą składa się z dwudziestu dwóch niepaginowanych stron. Tekst napisany został brązowym atramentem na papierze czerpanym, żeberkowym, z widocznymi filigranami. Dokument zszyty został razem z szarym, grubszym niż pozostałe karty papierem, pełniącym funkcję okładki. W górnej części (niebieską kredką) sporządzono adnotację: 1751. II Egz. Odbiorczy J. M. X. Rumszewicza Benedykta $\mathrm{Nr}$ oraz (czerwoną kredką) 7 a-6.

W centralnej części pierwszej strony znajduje się ujęty w ozdobny romb tytuł dokumentu: Inwentarz Koscioła i Plebanii Kossowskiej w Roku 1751. Miesiaca Januarii 19. dnia sporzadzony. U dołu czerwoną kredką zapisano litery $m f$ zawarte w kółku (to samo oznaczenie znajduje się na stronie dwudziestej drugiej, również u dołu). W prawym górnym rogu widnieje szereg ukośnych, równoległych linii (wykonanych być może w celu rozpisania pióra). Dodatkowo na stronie pierwszej umieszczono dwie naklejki sygnaturowe Archiwum Parafii Kossów. Strona druga wypełniona jest zapiskami i wprawkami kaligraficznymi różniącym się od pozostałego dokumentu charakterem pisma, wykonanymi prawdopodobnie ołówkiem kopiowym.

Tekst dokumentu napisany został po polsku oprócz doklejonej karty dziesiątej w języku łacińskim o incypicie: Decretum Visitationis seu Reformationis...

Pismo jest staranne, w tekście wyróżnia się podziały tematyczne oraz wykazy i tabele. W prawym dolnym rogu znajdują się reklamanty słowne.

Stan zachowania dokumentu jest dobry. Karty są stosunkowo czyste, powierzchniowe zabrudzenia oraz ślady po muchach można zauważyć na pierwszej i ostatniej stronie. Na stronie dwudziestej i dwudziestej drugiej widoczne są ślady po złożeniu papieru świadczące o tym, że dokument pierwotnie miał inną formę.

Dokument jest zabezpieczony tekturową teczką opatrzoną naklejkami sygnaturowymi.

$$
* * *
$$

\section{Inwentarz kościoła i plebanii w Kossowie - 1751 r. Decretum Reformationis par. Kossów - 1756 r.}

[k. 1r] Inwentarz kościoła i plebanii kossowskiej w roku 1751 miesiąca Januarii 19. dnia sporządzony.

[k. 2r] Inwentarz kościoła i plebanii kossowskiej roku 1751 miesiąca Januaria 19 dnia sporządzony przeze mnie, księdza Krzysztofa Modzelewskiego, dziekana różańskiego, plebana międzyrzeckiego, przy podaniu plebanii kossowskiej jego- 
mości księdzu Benedyktowi Rumszewiczowi ${ }^{1}$ post investituram ${ }^{2}$ na pomienioną plebanię z opisaniem plebanii, kościoła i w nim supellectiów ${ }^{3}$, item budynków plebańskich, wiosek, stawu, młynu, juryzdyki, tudzież gruntów i łąk do plebanii należących.

\section{Naprzód opisanie Kościoła}

Kościół drewniany, starodawny, drzewa dobrego, fundowany pod tytułem Świętej Trójcy i Świętego Krzyża od J[aśnie] W[wielmożnego] imć Pana Lwa Sapiehy ${ }^{4}$ wojewody wileńskiego, hetmana W[ielkieg]o X[ięstwa] L[itewskieg] $\mathrm{z}$ wieżą jedną pod facjato opatrzony ab extra doskonale, kosztem niedawno przeszłego j[egomości] księdza plebana i jest tarczycami ${ }^{5}$ circum circa obity, i z pokostem malowany instar ${ }^{6}$ cegły, także i wieża cała obita, Krzyż pozłacany fangultem ${ }^{7}$, pukle i gałka miedziana pozłociste, wierzchnia kondygnacja alias kopuła blacho dawno pobita. Dach całego kościoła czerwono ze smoło pokostem malowany, drzwi do kruchty z obu stron idą podwójne na zawiasach od dzwonicy z zaszczepką i zamkiem wiszącym, a drugie z zaporą drewnianą. Drzwi do samego kościoła pojedynkowe na trzech zawiasach z zamkiem wnętrznym drugim wiszącym na łańcuchu z zaszczepką, ściany malowane w brety ${ }^{8}$ farbo szarą, także i sufit z podbitką nad wielkim ołtarzem rożne osoby święte i floresy malowane, okien w kościele pięć w ołów robione, a szóste nad zakrystią z kraty na chórze okien trzy, w drzewo robione czerwono malowane. Belka wpośród kościoła na której krucyfiks rznięty, z jednej strony $S[=$ =́więtego] Jana, a z drugiej Najświętszej Panny, statui malowane. Posadzka przed wielkim ołtarzem czarną farbą przez cegłę malowana [k. 2v]. A na środku kościoła podłoga tarczyczna przy pobocznym ołtarzu sklep murowany, z podwórza okno jedne z kratą żelazną, do niego

${ }^{1}$ Rumszewicz Benedykt - proboszcz w Kosowie od stycznia 1751 roku, który przejmując parafię kosowską podpisał odbiór inwentarza sporządzonego przez księdza dziekana Krzysztofa Modzelewskiego.

${ }^{2}$ Investitura (łac.) - nominacja.

${ }^{3}$ Supellex, supellectilis (łac.) - sprzęt kościelny, liturgiczny.

${ }^{4}$ Sapieha Lew herbu Lis (1557-1633), syn Iwana i brat Andrzeja. W młodości oddany był na dwór Mikołaja Radziwiłła Czarnego, studiował z jego synami w latach 1570-1573 w Lipsku, gdzie uległ protestantyzmowi, odszedł od prawosławia i został kalwinem. Dzięki Radziwiłłom dostał się w 1579 roku na dwór króla Stefana Batorego. W roku następnym został mianowany sekretarzem królewskim, a w kolejnym awansowany na pisarza litewskiego. W 1585 roku otrzymał urząd podkanclerzego litewskiego, następnie był administratorem skarbu litewskiego, a co za tym idzie zarządcą mennicy w Wilnie. W dużej mierze wpływał na politykę wschodnią Rzeczypospolitej. W 1586 roku przeszedł ostatecznie na katolicyzm. W 1589 roku otrzymał kanclerstwo litewskie, a od 1593 roku pełnił obowiązki trybunała litewskiego. Prowadził kampanię przeciwko powierzaniu urzędów litewskich osobom pochodzącym z Korony. Por. H. Lulewicz, Sapieha Lew herbu Lis, w: Polski Stownik Biograficzny, t. 35, Warszawa 1994, s. 84-102.

${ }^{5}$ Tarcica - materiał drzewny uzyskiwany przez pocięcie okrąglaków równolegle do ich osi podłużnych, tu także otrzymana $\mathrm{w}$ ten sposób deska.

${ }^{6}$ Instar (łac.) - na kształt.

${ }^{7}$ Fungult z niem. Feingold - czyste złoto.

${ }^{8}$ Bret z niem. Brett - deski, pasy. 
drzwi na zawiasach z zaszczepką, ławek w kościele dwanaście, quondam ${ }^{9}$ były malowane. Pod chórem ławek dwie, przy zakrystii ławka jedna malowana dobra, ławka pojedynkowa przy ambonie, krzeseł prostych dwie, na ścianach obicie stare w paski.

Ołtarz wielki stolarskiej roboty, czarno malowany, z kolumnami dwoma, partim $^{10}$ posrebrzane, w nim obraz Najśw[iętszej] Panny Maryi de Gratiis albo Łaskawej nazwany, ofiarowany i oddany do tego kościoła, od J[aśnie] W[wielmożnego] imć Pana Lwa Sapiehy, u tego ołtarza gradusów ${ }^{11}$ dwa, sama mensa ${ }^{12}$ murata, comportatili fido consecrato, na wierzchu tego ołtarza obraz $\mathrm{P}$ [ana] Jezusa z Najśw[iętszą] Panną i Ś[więtym] Janem stojącym malowane. Na tym ołtarzu z jednej strony Ś[więtego] Stanisława Biskupa Krakowskiego Męczennika, a z drugiej Ś [więtego] Kazimierza, u tegoż ołtarza ciborium ${ }^{13}$ drewniane stolarskiej roboty czarno malowane, filarków cztery, partim posrebrzane i pozłocone drzwiczki na zawiasach z zameczkiem wnętrznym, ciborium intra ${ }^{14}$ blaszką metalową żołtą wybite, przy wielkim ołtarzu z obu stron ołtarzyki niewielkie. Jeden Ś[więteg]o Michała, a drugi Ś[więtego] Antoniego z zasłonkami adamaszkowymi staremi. Czwarty ołtarz Ś [więtej] Anny Samotrzeciej, snicerskiej ${ }^{15}$ roboty, złotem i srebrem malowane, w niektórych miejscach winogrona malowane, zielono wyrzynane, na wierzchu tego ołtarza pod krzyżykiem obrazek Najśw[iętszej] P[anny] Ofiarowania, mensa u tego ołtarza murowana, consecrata ${ }^{16}$, Ołtarz balaskami malowanymi opierzony, drzwiczki z balasków na zawiasach. Piąty ołtarz snicerskiej roboty na dwóch filarach podobny ołtarzowi Ś[więtej] Anny, w nim obraz Najś[więtszej] Panny z zasłonko dwoisto, mensa murowana consecrata, ołtarz balaskami malowanemi opierzony, drzwiczki na zawiasach. Ambona snicerskiej roboty, $z$ koroną nową nad amboną malowaną. Baptisterium snicerskiej roboty na zawiasach, drzwiczki na zawiasach z zaszczepką i zamkiem wiszącym malowana różnymi farbami, na koło balaskami malowanemi opierzone, drzwiczki drugie $\mathrm{z}$ balasów takichże. Vas novum ${ }^{17} \mathrm{z}$ nakrywko drewnianą i łyżka cynowa [k. 3r], na chór wchodząc gradusy stare, do nich drzwi na zawiasach z zaszczepkami z obu stron, na chórze organ stojący nowy przez imć ks. plebana sporządzony przeszłego, z kolumnami dwoma, chór od kościoła balasami malowanymi opie-

\footnotetext{
${ }^{9}$ Quondam (łac.) - niegdyś.

${ }^{10}$ Partim - częściowo.

${ }^{11}$ Gradus (łac.) - stopień.

${ }^{12}$ Mensa (łac.) - płyta ołtarzowa, główna część ołtarza. Mensa ołtarza stałego winna być ka-

${ }^{13}$ Cyborium (grec.) - naczynie służące do przechowywania lub przenoszenia Najświętszego Sakramentu. Umieszczone w tabernakulum, służy do przechowywania tzw. małych komunikantów do rozdzielania wiernym.

${ }^{14}$ Intra (łac.) - wewnątrz.

${ }^{15}$ Snycerstwo - artystyczne rzemiosło, sztuka rzeźbienia w drewnie, dawniej także w kamieniu.

${ }^{16}$ Consecrata (łac.) - poświęcona.

${ }^{17}$ Vas novum (łac.) - nowe naczynie.
} mienna. 
rzony, tamże na chórze kotłów dwa miedzianych, bębien nowo sporządzony, tamże brewiarzów dwa, księga łacińska wielka, rosarium $^{18}$.

Zakrystia po prawym boku, drzwi na zawiasach, zamek wnętrzny z zaszczepką, okno w drzewo robione z kratą żelazną, stol[arka] tarczyczna, posadzka ceglana, szafa stara z trzema szufladami na ornaty; na tej szafie stół do ubierania się na Mszy Świętej. i trzy szafki na kielichy bez drzwiczek, skrzyń starych trzy miernych z zamkami wnętrznemi na bieliznę kościelną, sam kościół podmurowany cegłami nad podmurowaniem daszek około gontami ${ }^{19}$ kryty.

\begin{tabular}{|c|l|c|}
\hline L. p. & \multicolumn{1}{|c|}{ Argenterie kościelne } & Sztuki \\
\hline 1 & Puszka pozłocista ad conservandum Sanctissimum $^{\mathrm{a}}$ & 1 \\
\hline 2 & Kielich srebrny wewnątrz pozłocisty & 1 \\
\hline 3 & Item kielich mosiężny z ... srebrną (przekreślony) $^{\mid}$ & 1 \\
\hline 4 & Kielich pozłocisty cały mosiężny & 1 \\
\hline 5 & Item kielich srebrny & 1 \\
\hline 6 & Monstrancja mosiężna pozłocista, korona i melchisedech ${ }^{\text {b srebrny }}$ & 3 \\
\hline 7 & Taca i ampułki miedziane pozłociste sztuk & 1 \\
\hline 8 & Trybularz mosiężny z fajerką żelazną & 1 \\
\hline 9 & Lampa srebrna przed wielkim ołtarzem wisząca & 3 \\
\hline 10 & $\begin{array}{l}\text { przy tej lampie łańcuszków trzy, która jak świadczy rewizja dawniej- } \\
\text { sza, iż waży grzywien }{ }^{\mathrm{d}} \text { i łutów 6 }\end{array}$ & 7 \\
\hline 11 & u wielkiego ołtarza tabliczek małych & 17 \\
\hline 12 & Tabliczek większych & 2 \\
\hline 13 & Kołnierz srebrny & $\begin{array}{l}\text { Relikwiarzów na wielkim ołtarzu alias obrazków rożnych w szkło } \\
\text { szlifowanych oprawnych, i na szkle malowanych }\end{array}$ \\
\hline 14 & Lichtarzyków mosiężnych pobielanych dwa & 14 \\
\hline 15 &
\end{tabular}

${ }^{a}$ Ad conservandum Sanctissimum (łac.) - do przechowywania Najświętszego Sakramentu.

${ }^{\mathrm{b}}$ Melchisedech, melchizedek (bibl.) - inaczej kustodia, naczynie liturgiczne do przechowywania $\mathrm{w}$ tabernakulum konsekrowanej hostii, przeznaczonej do umieszczania $\mathrm{w}$ monstrancji podczas nabożeństw eucharystycznych lub adoracji Najświętszego Sakramentu. Wykonany ze szlachetnego metalu, wewnątrz był pozłacany lub posrebrzany.

c Trybularz, właśc. turybularz (łac. turibulum) - naczynie służące do okadzania ołtarza, darów ofiarnych, Najświętszego Sakramentu, Ewangeliarza, krzyża, figur, uczestników liturgii. Wykonane z metalu, jego nakrycie (przykrywka) umocowana jest na trzech łańcuszkach. Do tego naczynia, w którym są rozżarzone węgle, wsypuje się ziarenka kadzidła.

${ }^{\mathrm{d}}$ Grzywna - dawna jednostka wagi.

${ }^{18}$ Rosarium (łac.) - różaniec.

${ }^{19}$ Gont - deszczułka klinowa używana do pokrywania dachów lub szalowania zewnętrznych ścian budynków. 


\begin{tabular}{|c|c|c|}
\hline 16 & $\begin{array}{l}\text { Lichtarzów cynowych wielkich u wielkiego ołtarza sześć darowa- } \\
\text { nych od W[ielmożnego] imć p[ana] Kościuszki miecznego w[ojewó] } \\
\mathrm{d}[\mathrm{z}] \text { twa brz[eskiego] }\end{array}$ & 6 \\
\hline 17 & Krzyż cynowy alias pacyfikał jeden & 1 \\
\hline $\begin{array}{l}{[\mathrm{k} .3 \mathrm{v}]} \\
18\end{array}$ & $\begin{array}{l}\text { Ampułek cynowych z tacami par trzy, kosztem teraźniejszego jego- } \\
\text { mości ks. plebana sprawione }\end{array}$ & 3 \\
\hline 19 & Lichtarzów drewnianych wszystkich par siedm & 7 \\
\hline 20 & Krucyfiksów drewnianych na ołtarzach cztery & 4 \\
\hline 21 & Processjonalnych krzyżów dwa, jeden w zakrystyi, drugi w kościele & 2 \\
\hline 22 & Kociołek miedziany z kabłuczkiem żelaznym na wodę święconą & 1 \\
\hline 23 & $\begin{array}{l}\text { Dzwonek wiszący przy zakrystyi, drugi dzwonek w samym babiń- } \\
\text { cu }^{\mathrm{f}} \text {, alias sygnaturka }\end{array}$ & 2 \\
\hline 24 & Dzwonków małych dwa, kupionych przez teraźniejszego plebana & 2 \\
\hline 25 & Dzwonków dawniejszych trzy & 3 \\
\hline \multicolumn{3}{|c|}{ Aparaty } \\
\hline 1 & $\begin{array}{l}\text { Kapa czerwona adamaszkowag }{ }^{\mathrm{g}} \text {, listwa i szczyt adamaszkowy niebie- } \\
\text { ski z kompaną } \text { białą srebrną }^{\text {s. }}\end{array}$ & 1 \\
\hline 2 & Kapa żałobna gradyturowai jednostajna, obłożona taśmą półjedwabną & 1 \\
\hline 3 & $\begin{array}{l}\text { Ornat światły bogaty lamowy }{ }^{\mathrm{j}} \mathrm{w} \text { rozmaitych kwiatach z kolumną } \\
\text { jednostajną kompanką obłożony, z całym garniturem }{ }^{\mathrm{k}} \text { to jest stuła, } \\
\text { manipularz, velum }^{1} \text {, bursa }{ }^{\mathrm{m}} \text { i palka }\end{array}$ & 1 \\
\hline
\end{tabular}

${ }^{\mathrm{e}}$ Ludwik Tadeusz Kościuszko (1700-1758) herbu Roch III, miecznik województwa brzeskiego, pułkownik 3 Pułku Straży Przedniej Buławy Polnej Litewskiej, ojciec Tadeusza Kościuszki. W 1740 r. poślubił Teklę z Ratomskich. W spadku od ojca otrzymał zaniedbany i zadłużony majątek rodowy, dlatego przekazał Siechnowicze Małe ze Stepankami, Nowosiółkami i Konotopami swemu wujowi Faustynowi Benedyktowi, sam biorąc w dzierżawę od Sapiehów folwark Mereczowszczyzna koło Kosowa Poleskiego.

${ }^{\mathrm{f}}$ Babiniec - staropolska nazwa kruchty kościelnej, czyli przedsionka w kościele; nazwa pomieszczenia przeznaczonego dla kobiet. Kościoły większe miały również babińce boczne przy wejściach bocznych.

g Adamaszek - tkanina, zwykle jednobarwna, dwustronna, o wzorze z jednej strony matowym, z drugiej błyszczącym.

${ }^{\mathrm{h}}$ Kompanka, kampanka - wąska prosta koronka klockowa lub cienka wąska tasiemka z tiulu klockowego, doszywana na brzegu kosztownych koronek celem ich poszerzenia.

${ }^{\mathrm{i}}$ Grodetur (franc.), grady tur, gredytur, grodytur, drodetur - gęsta tkanina jedwabna, barwiona na różne kolory, czasem wzorzysta, używana do haftów jedwabiem i nicią metalową.

${ }^{j}$ Lama - głodka lub wzorzysta tkanina jedwabna o tle całkowicie lub częściowo pokrytym dodatkowym wątkiem metolowym złotym lub srebrnym, rzadko obydwoma, najczęściej w postaci pasków folii. Używana na kosztowne ubiory świeckie i liturgiczne.

${ }^{\mathrm{k}}$ Garnitur -zespół przedmiotów służących do jednego celu, stanowiących pewną całość.

${ }^{1}$ Velum (łac.) - zasłona.

${ }^{m}$ Bursa - parament liturgiczny w kształcie kwadratowej teczki używany do mszy lub przenoszenia wiatyku. Bursa mszalna do której wsuwa się korporał. Dostosowana jest do koloru szat liturgicznych, zdobiona zazwyczaj symbolem liturgicznym. Obecnie nie używana w liturgii. Bursa zamknięta służy do przenoszenia Najświętszego Sakramentu do chorych.

${ }^{n}$ Palka - kwadratowe przykrycie kielicha mszalnego używane podczas liturgii. Wykonane ze sztywnego płótna, chroni kielich przed zanieczyszczeniami. Palkę umieszcza się na kielichu razem z korporałem i puryfikaterzem i nakrywa się przed Mszą Świętą welonem. 


\begin{tabular}{|c|c|c|}
\hline 4 & $\begin{array}{l}\text { Ornat czerwony lamowy kwiaty złote, z kolumną jednostajną kom- } \\
\text { panka srebrna, stuła, manipularz, kraszaniną }{ }^{\circ} \text { niebiesko podszyty }\end{array}$ & 1 \\
\hline 5 & $\begin{array}{l}\text { Ornatów dwa adamaszkowych fijałkowych jednostajnych, jeden } \\
\text { kompanką białą obłożony, drugi żołtą jedwabną }\end{array}$ & 2 \\
\hline 6 & $\begin{array}{l}\text { Ornat czerwony adamaszkowy, z kolumną jednostajną stuła i mani- } \\
\text { pularz }\end{array}$ & 1 \\
\hline 7 & $\begin{array}{l}\text { Ornat czerwony lamowy srebrem haftowany fundatorski kolumna } \\
\text { jednostajna z kompanką srebrną, kraszaniną podszyty, do niego stuła } \\
\text { i manipularz }\end{array}$ & 1 \\
\hline 8 & $\begin{array}{l}\text { Ornat czerwony atłasowy kolumna adamaszkowa w kwiaty złote, ta- } \\
\text { siemką półjedwabną, podszyty kraszaniną niebieską }\end{array}$ & 1 \\
\hline 9 & $\begin{array}{l}\text { Ornat czerwony adamaszkowy, z kolumno taką, jak w atłasowym ta- } \\
\text { siemką półjedwabną obłożony, stuła i manipularz }\end{array}$ & 1 \\
\hline [k. 4r] 10 & $\begin{array}{l}\text { Ornat czerwony kitajkowy jednostajny z tasiemką półjedwabną, stuła } \\
\text { i manipularz kraszaniną podszyty }\end{array}$ & 1 \\
\hline 11 & $\begin{array}{l}\text { Ornat czerwony bogaty, kwiaty srebrne, kolumna biała bogatej lamy }{ }^{\mathrm{r}} \text {, } \\
\text { kompanka złota, stuła i manipularz }\end{array}$ & 1 \\
\hline 12 & $\begin{array}{l}\text { Ornat niebieski gradyturowy z kolumną białą atłasową kwiaty wyszy- } \\
\text { wane, galonik szychowy żółty, stuła i manipularz }\end{array}$ & 1 \\
\hline 13 & $\begin{array}{l}\text { Ornat włóczkowy szyty, totaliter }{ }^{r} \text { podszyty kitajką niebieską, stuła i } \\
\text { manipularz }\end{array}$ & 1 \\
\hline 14 & $\begin{array}{l}\text { Ornat zielony lamowy z kolumną jednostajną kompanka złota, krasza- } \\
\text { niną podszyty, stuła, i manipularz }\end{array}$ & 1 \\
\hline 15 & $\begin{array}{l}\text { Ornat fijałkowy adamaszkowy z światlejszą kolumną, tasiemką tylo } \\
\text { około kolumny jedwabno obłożony }\end{array}$ & 1 \\
\hline 16 & $\begin{array}{l}\text { Ornat włosowy atłasowy, kwiatki z gęsta wyszywane kolumna żołta } \\
\text { galonik wkoło żołty, a przy kolumnie biały }\end{array}$ & 1 \\
\hline 17 & Ornat czarny atłasowy, kolumna włosowa atłasowa & 1 \\
\hline 18 & $\begin{array}{l}\text { Ornat czarny stary, kolumna w kostki włóczkowa, druczkiem mo- } \\
\text { skiewskim podszyty, do tych ornatów stuły, manipularze, wela i palki }\end{array}$ & 1 \\
\hline \multicolumn{3}{|c|}{ Bielizna kościelna $\mathrm{i}$ inne apparencja } \\
\hline 1 & Alb dużo zażywanych & 6 \\
\hline 2 & Humerałów & 6 \\
\hline 3 & Komż starych & 2 \\
\hline 4 & Komeżek starych & 2 \\
\hline 5 & Ręczników starych grubych & 5 \\
\hline 6 & Pasków superfinowych starych & 3 \\
\hline 7 & Pasek żałobny & 1 \\
\hline
\end{tabular}

${ }^{\circ}$ Kraszenina - barwione, woskowane płótno, wyrabiane na Rusi w XVI-XVII wieku.

${ }^{\mathrm{p}}$ Kitajka (ros. Kitaj, Chiny) - cienka, gęsto tkana splotem płóciennym, materia jedwabna. Jedna z najstarszych i najprostszy rodzaj tkaniny jedwabnej wyrabianej na Wschodzie.

${ }^{\mathrm{r}}$ Totaliter (łac.) - całkowicie, zupetnie. 


\begin{tabular}{|c|c|c|}
\hline 8 & Korporałów nowych teraz sporządzonych & 9 \\
\hline 9 & Puryfikaterzów ${ }^{s}$ także teraz sporządzonych & 12 \\
\hline 10 & Tuwalńt $^{t}$ wyszywanych złotem i srebrem w kwiaty & 2 \\
\hline 11 & Tuwalń rożnych tkackich & 8 \\
\hline 12 & Obrusów różnych & 10 \\
\hline 13 & $\begin{array}{l}\text { Antepedie }{ }^{u} \mathrm{u} \text { wielkiego ołtarza ponsowe } \mathrm{z} \text { galonami srebrnemi, teraz } \\
\text { sporządzone }\end{array}$ & 1 \\
\hline $\begin{array}{c}{[k .4 v]} \\
14\end{array}$ & W pobocznych ołtarzach antepedie kartunowe płótnem podszyte & \\
\hline 15 & $\begin{array}{l}\text { Nakrywki do wszystkich pięciu ołtarzów z płótna grubego quondam } \\
\text { żółto malowane }\end{array}$ & 5 \\
\hline 16 & Biret nowy teraz sporządzony & 1 \\
\hline 17 & & 8 \\
\hline 18 & Dywan wielki do zasłania przedniej ławki & 1 \\
\hline 19 & Całun bracki & 1 \\
\hline 20 & Baldachimw adamaszkowy stary na czterech drążkach & 1 \\
\hline 21 & Portatilów ${ }^{x}$ na ołtarzach & 3 \\
\hline 22 & $\begin{array}{l}\text { Portatil jeden wielki u Świętej Anny, kupiony przez teraźniejszego ple- } \\
\text { bana }\end{array}$ & 1 \\
\hline 23 & Mszałów starych & 3 \\
\hline 24 & Agenda stara & 1 \\
\hline 25 & Agenda wielka nowa, teraz kupiona, kosztująca talarów ${ }^{y}$ bitych sześć & 1 \\
\hline 26 & Metryka dawniejsza & 1 \\
\hline 27 & Metryk nowych teraz sprawionych & 3 \\
\hline 28 & Agendka stara i ewangeliczka & 2 \\
\hline 29 & $\begin{array}{l}\text { Zasłony u wielkiego ołtarza kitajczane żółte nowe, ofiarowane od imć } \\
\text { Pana Kościuszki miecznego brzeskiego }\end{array}$ & 1 \\
\hline
\end{tabular}

${ }^{\mathrm{s}}$ Puryfikaterz (z łac.) - ręcznik do wycierania rąk podczas czynności liturgicznych.

${ }^{t}$ Tuwalnia, towalia (wł.) - rodzaj szerokiego ręcznika, od w. XV wieku przywożone do Polski z Włoch. Tuwalnie były wzorzyste i zastępowały nieraz obrusy na stołach.

"Antependium (łac.) - zasłona lub zakrycie podstawy stałego ołtarza w kościele. Pierwotnie antepedia obiegały mensę ołtarza ze wszystkich stron, od XI wieku zakrywały jedynie przednią część. Wykonane ze złota lub srebra, często zdobione szlachetnymi kamieniami i filigranem, z tkanin haftowanych, drewna malowanego lub płaskorzeźbionego, ze skóry tłoczonej i złoconej. Na nich przedstawiano sceny z życia Chrystusa, Marii lub świętego, któremu był poświęcony ołtarz.

w Baldachim przenośny - ozdobna zasłona w kształcie daszka, rozpostarta na czterech drążkach. Używany w czasie procesji z Najświętszym Sakramentem, niesiony jest nad celebransem trzymającym monstrancję.

${ }^{x}$ Portatyl (łac. portatile) - niewielki ołtarz przenośny, na którym sprawowano Eucharystię poza świątynią, np. w więzieniach już w III wieku. Od IV wieku umieszczano relikwie świętych w ołtarzach i portatylach. Sprawowanie Eucharystii bez portatyla poza kościołem było zabronione. Posoborowa odnowa liturgii zniosła obowiązek stosowania portatyli przy sprawowaniu Eucharystii.

${ }^{y}$ Talar - dawna jednostka monetarna. 
Wschodząc z kościoła dzwonnica o dwóch kondygnacyach z drzewa brusowanego ${ }^{20}$ wiązana, tarczycami stojącymi naokoło obita, gontami kryta, czerwono farbą malowana. Dzwonów trzy, jeden większy, a dwa mniejsze.

Cmętarz od ulicy balasami pod daszkiem zarzucany w jeden barwionami, a środkiem balasy, wrota dwoiste od ulicy na cmętarz $\mathrm{z}$ forto pod daszkiem, $\mathrm{z}$ drugiej strony cmętarza od ogrodu i plebanii parkan ... zarzucony.

\section{Opisanie plebanii}

Idąc z ulicy wrota stare, dwoiste, na biegunach, z furtką, drzwiczki na zawiasach, daszek gontami pobijany, $z$ fundamentu reperacyi potrzebujące, dalej idąc po prawym boku budynek dla wikarego gontami pobijany, z sieńmi, izbą, komorą, i spiżarenką, w izbie piec kaflany, okien trzy [k. 5r] a w komorze jedne okno w drzewo robione, stol tarczyczna, kominek przez dach wywiedziony, z sieni idąc po prawym boku izdebka mała, piec kaflany, okno jedno, z obudwóch pieców dymy za jedno sprowadzone, drzwi pięcioro, $\mathrm{z}$ tych jedne na zawiasach, a inne na biegunach, od wrót po lewej stronie budynek dla rzemieślników, izba z sieńmi, komorą i komórką, piec kaflany per modum ${ }^{21}$ piekarnianego, z kominem przez dach wywiedzionym, okien trzy w drzewo robione, sam budynek gontami pobijany, w nim drzwi pięcioro na biegunach bez żadnego żelaza, dziedzińczyk tego budynku mały, parkanikiem z balasami oprowadzony. W końcu tego budynku stajen dwie dranicami ${ }^{22}$ pobijane, reperacji potrzebujące, do nich drzwi dwoje $\mathrm{z}$ dranic robione przy nich dwa chlewki słomo kryte. Rezydencja plebańska - do niej wchodząc ganek z balasami, drzwi do sieni na zawiasach, z sieni po lewej stronie izba do niej drzwi na zawiasach, piec kaflany fladrowy ${ }^{23}$, okien trzy $\mathrm{w}$ drzewo robione, komora $\mathrm{z}$ alkierzykiem, drzwi oboje na zawiasach, w alkierzyku piec kaflany, okien dwie w drzewo robione, a w komorze jednej ex op $[p] o s i t o^{24}$ siebie przez sieni izdebka mała, drzwi na zawiasach z kruczkiem, piec fladrowy z kominkiem, okien dwie w drzewo robione, stol tarczyczna, posadzka z cegieł; $\mathrm{z}$ izby komora, drzwi dębowe na zawiasach, z zamkiem wnętrznym, okno jedne w ołów robione, z komory alkierzyk z małą spiżarenką, drzwi na biegunach, jedne $\mathrm{z}$ zaszczepką, okien dwie w drzewo robione, z komory do kuchenki drzwi na zawiasach; przy kuchence spiżarenka, drzwi na biegunie, z tych pieców dymy do jednego komina sprowadzone kuchennego; ten budynek gontami pobijany, z fundamentu nowej reperacji potrzebujące, w izbie pierwej opisanej szafa stolarskiej roboty na kształt kredensu przez teraźniejszego księdza plebana sporządzona, w drugiej izbie szafka mała przy drzwiach stoi, do niej drzwiczki na zawiasach.

${ }^{20}$ Brusowany - szlifowany.

${ }^{21}$ Per modum (łac.) - na sposób.

${ }^{22}$ Dranica - cienka, wąska deska łupana z pnia drzewa iglastego, używana w budownictwie drewnianym, zazwyczaj do krycia dachów (dranka).

${ }^{23}$ Fladrować - malować na drewnie lub kamieniu.

${ }^{24}$ Ex opposito (łac.) - naprzeciw. 
Za budynkiem syrnik ${ }^{25}$ stary na słupach, zrzucenia godny. Swiron ${ }^{26}$ spory, słomą kryty, z gankiem, drzwi na biegunie z zaszczepką i z zamkiem wnętrznym i wiszącym, w nim zasieków z dolnymi i pod dachem trzynaście [k. 5v], drugi swiron mniejszy, do niego drzwi na biegunie z zamkiem wiszącym i z zaszczepką dranicami kryty, w nim zasieków sześć, podle tego swironka chlewów cztery pod jednym dachem słomą kryte, do nich wrota $z$ dranic robione, dalej idąc odryn ${ }^{27}$ dwie pod jednym dachem, wrota $\mathrm{z}$ dranic robione $\mathrm{z}$ zasuwkami drewnianemi, klucze żelazne.

Gumno ${ }^{28}$ wielkie, do niego wrót dwoje $\mathrm{z}$ tarczyc robione, słupów dwanaście do składania zboża, słomą kryte.

Gumno drugie mniejsze, wrota tarczyczne, słupów dziewięć przy gumnach zamków dwa z zaszczepkami.

Przepłotów ${ }^{29}$ na zboże czternaście, przy gumnie naokoło gumna, przy gumnie żerdziami ogrodzone, od gumien idąc po lewej stronie chlewków dwa, tamże pod jednym nakryciem słomianym odryna i stajen dwie, drzwi z descek [sic] robione.

Browar dranicami pokryty, z zamkiem wiszącym i zaszczepką, w nim czopów trzy, trąbnica jedna, i komóreczka mała.

Warzywnia za browarem nowo wybudowana słomą kryta z sieńmi, drzwi na biegunie tarczyczne, okien małych trzy z zasuwkami, Dalej idąc piekarnia stara wakująca z sieńmi i komórką, okien cztery z zasuwkami dranicami kryta. Item druga piekarnia mieszkalna stara, z sieńmi i komórką, dranicami kryta, piec piekarniany, okien cztery szklane, pocios z descek [sic], drzwi wszystkie na biegunach, w sieniach kuchnie z kominem przez dach wywiedzionym między czterma słupami, naprzeciw piekarni spiżarenka, okien cztery, piec piekarniany z kominem przez dach wywiedzionym, z spiżarni idąc komóreczka dla złożenia rzeczy drzwi, na biegunie piekarnie i spiżarenka pod jednym dachem dranicami krytym w kuchni wyżej pomienionej obłożyny żelazne na hakach żelaznych, z piekarni idąc ku kościołowi piwnica z kamieni murowana, we środku tarczycami przepierzona, drzwi dwoje na zawiasach z zaszczepkami i zamkami, nad piwnicą swironek z drzewa okrągłego, drzwi na zawiasach z zaszczepką i zamkiem wnętrznym gontami kryty, w nim zasieków cztery pod dach schowanie, przy swironku wozownia dla schowania sprzętu gospodarskiego, drzwi na biegunie z zaszczepką i zamkiem wiszącym dranicami kryta.

[k. 6r] Łaźnia w sadzie z sionkami, słomą kryta, drzwi troje na biegunach, okien trzy z zasuwkami, tamże za łaźnią sadzawek trzy na ryby. Parkan około plebanii w szuty zarzucany około sadu i ogrodów, częścią parkanem częścią żerdziami ogrodzona.

${ }^{25}$ Syrnik, sernik - budynek o przewiewnej konstrukcji do przechowywania serów.

${ }^{26}$ Swiron, ściągnięte z języka litewskiego - spichlerz.

${ }^{27}$ Odryna - regionalna (białoruska) nazwa budynku, przeważnie drewnianego, w którym przechowuje się siano.

${ }^{28}$ Gumno - budynek w którym składa się zboże przed wymłóceniem, stodoła.

${ }^{29}$ Przepłot - rodzaj szerokiej drabiny nieruchomej ze słupów i żerdzi poprzecznych do suszenia zboża, grochu, jęczmienia itp. 
Młyn we wsi Storożowszczyznie na dwa koła z żelazem młynowym i wszelkim porządkiem do niego należącym, sam młyn z drzewa brusowanego, gontami pobijany, wietrznica na wierzchu, spust reperacji potrzebujący, drzewo na spust sprowadzone przy młynie.

Grunta plebańskie tu się nie specyfikują morgami ani włókami, tylko dwa poletki, jeden na Łopieniewszczyznie, tamże i sianożęćc ${ }^{30}$, drugi poletek częścią na jare zboże wygnojone pod młynem plebańskim gdzie quondam był młyn, a teraz tylko znak tego miejsca, sianożęć nad rzeczką, trzeci poletek na Pustkach Włocznym Gruncie, który przed tym poddani plebańscy zarabiali, teraz plebania zasiewa. Jednak tego gruntu potrzebującym poddanym plebańskim imć ksiądz pleban nie ma bronić biorącym na osiadłość lub na czynszu trzymać chcącym.

\begin{tabular}{|c|l|c|}
\hline L.p. & \multicolumn{1}{|c|}{ Obora } & Sztuki \\
\hline 1 & Krowa & 1 \\
\hline 2 & Owiec & 15 \\
\hline 3 & Świń z wieprzami & 17 \\
\hline 4 & Gęsi z gęsiorami & 10 \\
\hline 5 & Kaczek z kaczorami & 10 \\
\hline 6 & Kur z kogutami & 11 \\
\hline 7 & Kapłonów ${ }^{\text {aa }}$ & 3 \\
\hline \multicolumn{2}{|c|}{ Mięsiwo } \\
\hline 1 & Słoniny połciów & 2 \\
\hline 2 & Sadeł & 2 \\
\hline 3 & Kumpi ${ }^{\text {bb }}$ par & 3 \\
\hline 4 & Wędzonek par & 4 \\
\hline
\end{tabular}

\begin{tabular}{|c|c|c|}
\hline L.p. & [k. 5v] Zboże & Kopy/Wozy \\
\hline 1 & Żyta użętego kop ${ }^{c c}$ & 40 \\
\hline 2 & Jęczmienia użętego kop & 45 \\
\hline 3 & Tarki kop & 12 \\
\hline 4 & Pszenicy kop & 10 \\
\hline 5 & Owsa kop & 30 \\
\hline 6 & Gryki kop & 20 \\
\hline 7 & Grochu wozów & 4 \\
\hline 8 & Bobu kop & 4 \\
\hline 9 & Siana wozów & 50 \\
\hline 10 & Żyta zasianego na rok 1751 szanków ${ }^{\mathrm{dd}}$ & 15 \\
\hline
\end{tabular}

${ }^{\text {aa }}$ Kapłon - samiec kury domowej (kogut), kastrowany w celu szybszego utuczenia lub uzyskania smaczniejszego mięsa.

${ }^{\mathrm{bb}}$ Kumpie - rodzaj wędliny.

${ }^{c c}$ Kopa - sześćdziesiąt sztuk. Dawna jednostka obrachunkowa, używana obecnie czasami na wsi.

dd Szank, szanek (z niem. Schank) - miara objętości towarów sypkich, zwykle zboża, obejmująca 24 lub 48 garnców. Garniec - dawna polska miara objętości, zawierająca cztery kwarty, czyli w przybliżeniu cztery litry.

${ }^{30}$ Sianożęc - łąka na której kosi się trawę (siano), jako karma dla bydła na zimę. 


\begin{tabular}{|c|l|c|}
\hline L.p. & \multicolumn{1}{|c|}{ Naczynie gumienne i inne gospodarskie } & Sztuki \\
\hline 1 & $\begin{array}{l}\text { Szanek, czwiertka, i osmina do mierzenia zboża } \\
\text { sztuk }\end{array}$ & 3 \\
\hline 2 & Zabojen do z sypania zboża & 12 \\
\hline 3 & Beczek nowych i starych & 1 \\
\hline 4 & Lejka do zlewania piwa w piwnicy & 3 \\
\hline 5 & Cebrów ${ }^{\text {ee }}$ do noszenia wody & 2 \\
\hline 6 & Wiader także do noszenia wody & 1 \\
\hline 7 & Kwaśnik do sycenia miodu & 6 \\
\hline 8 & Kadzi warzywnych & 3 \\
\hline 9 & Koryt do siekania kapusty & 2 \\
\hline 10 & Dzież do pieczenia chleba & 2 \\
\hline 11 & Dojnic do mleka & 3 \\
\hline 12 & Necołek & 3 \\
\hline 13 & Przetaków & ff \\
\hline
\end{tabular}

\section{[k. 7r] Juryzdyka plebańska}

Domów z pustkami in universum ${ }^{31}$ trzydzieście, imiona i przezwiska jurysdyczan tu się nie specyfikuje dla różnych okoliczności, a nadto że domów pustych niemało się znajduje, a w nich chociaż mieszkają podkomornicy, to tylko do czasu, jednak placowe niechybnie podług dawnego zwyczaju corocznie jegomości ks[iędzu] plebanowi dochodzi placów funduszem nadanych jako świadczą dawniejsze i teraźniejsze dokumenta, znajduje się dwadzieścia siedem krom cmętarza i starej cerkwi.

Takoż placów trzy, kościołowi kossowskiemu pod miastem leżących, excep$t o^{32}$ funduszowych legował imć pan Saul Juszkiewicz ${ }^{33}$, porucznik J[ego] K[rólewskiej] M[o]ści w roku 1646, dnia 7 marca, wiecznymi czasy przy osobliwszym na to dokumencie, których juryzdyczanie używają.

\section{Powinność juryzdyczan}

Z każdego placu płacić mają po gr[oszy] 15 do żniwa z każdego placu dni sześć, siódmy dzień gwałtu ${ }^{34}$ odprawić mają do dzwonienia, do warty, na noc pod kościół kolejno chodzić powinni, do łowienia ryb na rzekę Hrywdę i na Grabarkę

\footnotetext{
${ }^{\text {ee }}$ Ceber - (przestarzałe) okrągłe naczynie z klepek, zwykle o dwóch uchach, używane na wsi.

${ }^{\mathrm{ff}}$ Przetak - rodzaj grubego sita, z większymi otworami, służący zwykle do odsiewania, oczyszczania zboża.

${ }^{31}$ In universum (łac.) - ogółem.

${ }^{32}$ Excepto (łac.) - wyjąwszy.

${ }^{33}$ Juszkiewicz Samuel - rotmistrz pieszy królewski, za zasługi wojenne. Zebrawszy na swój koszt oddział żołnierzy, walczył ze Szwedami, za co otrzymał wsie Jonance (Kudrawce), Lepogiry i Steltynie, w powiecie wiłkomirskim. Służył także jako porucznik husarski u, wojewody wileńskiego Sapiehy. Ze Żmudzi przeniósł się do Prus, gdzie pojął za żonę wdowę Zofię Milewską. Ich syn Jan (ur. 1691) został jezuitą, wyświęcony w 1700 roku. Por. K. Niesiecki, Herbarz polski, t. 4, Warszawa 1989, s. 517.

${ }^{34}$ Gwałt (z niem. Gewalt) - tu: przymusowe świadczenie robocizny.
} 
do młynu plebańskiego z czym każą, chodzić mają. Inna zaś posługa kościelna i plebańska starodawnemu zwyczajowi podlega, osobliwie z processami i listami bez żadnej ekskuzy ${ }^{35}$ chodzić powinni, gdzie zajdzie rozkaz jegomości księdza plebana.

Placów dwa, z tychże 27 fundatorskich excypowanych ${ }^{36}$ dla zakrystiana, i kantora, z których tylko posługa kościelna, a do żadnej płacy nie mają być pociągani.

Szpital dranicami kryty z sieńmi i izbą, drzwi dwoje na biegunach, piec piekarniany, okien pięć szklanych z zasuwkami, stol z descek ciosanych.

\begin{tabular}{|c|c|c|c|c|c|c|c|}
\hline Dymy & Syny & \multicolumn{2}{|c|}{ Włoki } & \multirow{2}{*}{$\begin{array}{c}{[\mathrm{k} .7 \mathrm{v}] \text { Wies }} \\
\text { Storożowszczyzna }\end{array}$} & \multirow{2}{*}{$\begin{array}{l}\text { Woły } \\
\text { sztuki }\end{array}$} & \multirow{2}{*}{$\begin{array}{l}\text { Konie } \\
\text { sztuki }\end{array}$} & \multirow{2}{*}{$\begin{array}{c}\text { Pszczoły } \\
\text { pnie }\end{array}$} \\
\hline osiadłe & Osoby & osiadłe & $\begin{array}{l}\text { czynszo- } \\
\text { we }\end{array}$ & & & & \\
\hline 1 & 2 & $1 / 4$ & $1 / 4$ & $\begin{array}{l}\text { Stefan Horbacz, syn } \\
\text { Ludwik, zięć Omelian }\end{array}$ & 1 & 2 & 5 \\
\hline 2 & 1 & $1 / 4$ & $1 / 4$ & $\begin{array}{l}\text { Benedys Samusiowej } \\
\text { z bratem Józefem }\end{array}$ & ” & 1 & $"$ \\
\hline 3 & 2 & $1 / 4$ & $1 / 4$ & $\begin{array}{l}\text { Jakub Borowik z sy- } \\
\text { nowcem Parmonem, } \\
\text { syn Leon Parmonow }\end{array}$ & ", & 1 & ", \\
\hline 4 & 1 & $1 / 4$ & $1 / 4$ & $\begin{array}{l}\text { Janko Haurusik, } \\
\text { syn Mikołaj }\end{array}$ & ” & 1 & $"$ \\
\hline 5 & 1 & $1 / 4$ & $1 / 4$ & $\begin{array}{l}\text { Jasko Arabej, } \\
\text { syn Dziemian }\end{array}$ & ” & 1 & ” \\
\hline 6 & 1 & $1 / 4$ & $1 / 4$ & $\begin{array}{l}\text { Stefan Sipuzik, } \\
\text { syn Ihnat }\end{array}$ & 1 & 1 & $"$ \\
\hline 7 & 1 & $1 / 4$ & $1 / 4$ & Jasko Andrejczyk & , & 1 & 2 \\
\hline 8 & 2 & $1 / 4$ & ” & $\begin{array}{l}\text { Anton Andrejczyk, } \\
\text { syny Michał i Jaśko }\end{array}$ & " & $"$ & $”$ \\
\hline 9 & , & $1 / 4$ & $1 / 4$ & Jaśko Danilczyk & , & , & , \\
\hline 10 & 2 & $1 / 4$ & $"$ & $\begin{array}{l}\text { Stefan Dragun, } \\
\text { syny Hrehor i Jaśko }\end{array}$ & $"$ & $"$ & $"$ \\
\hline 11 & 2 & $1 / 4$ & $1 / 4$ & $\begin{array}{l}\text { Jaśko Kozuszczyk } \\
\text { z bratem Wasilem, } \\
\text { syn Jaśkow Stefan }\end{array}$ & , & 1 & ", \\
\hline 12 & 1 & $1 / 4$ & $"$ & $\begin{array}{l}\text { Mikita Ihnacik, } \\
\text { syn Michaś }\end{array}$ & ” & 1 & 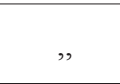 \\
\hline 13 & 2 & $1 / 4$ & $1 / 4$ & $\begin{array}{l}\text { Mateusz Horbacz, syn } \\
\text { Hryhor, zięć Samuś }\end{array}$ & ” & 1 & $"$ \\
\hline 14 & 2 & $1 / 4$ & $"$ & $\begin{array}{l}\text { Hryszko Bielewicz } \\
\text { z braćmi Niczyporem } \\
\text { i Antonem }\end{array}$ & " & ", & ", \\
\hline 15 & , & $1 / 4$ & , & Fiedor Ahapin & , & 1 & 4 \\
\hline
\end{tabular}

${ }^{35}$ Ekskuza (z łac. excusare) - wymówka.

${ }^{36}$ Ekscypowany (z łac. excipere) - wyjęty (spod obowiązku płacenia świadczeń). 


\begin{tabular}{|c|c|c|c|c|c|c|c|}
\hline 16 & 2 & $1 / 4$ & $"$ & $\begin{array}{l}\text { Jaśko Ahapin, } \\
\text { z bratem Leonem, } \\
\text { syn Jaśkow Józef }\end{array}$ & $"$ & 1 & $"$ \\
\hline 17 & 4 & $1 / 4$ & $1 / 12$ & $\begin{array}{l}\text { Paweł Tokarz, } \\
\text { syny Maciej, Oleś, } \\
\text { Pietruś i Jaśko }\end{array}$ & $"$ & $"$ & $"$ \\
\hline 18 & 1 & $1 / 4$ & $1 / 12$ & $\begin{array}{l}\text { Marcin Michalczyk, } \\
\text { syn Jaśko }\end{array}$ & $"$ & $"$ & $"$ \\
\hline 19 & 4 & $1 / 4$ & $1 / 4$ & $\begin{array}{l}\text { Chwedor Kozuszczyk } \\
\text { z bracią Janem, Paw- } \\
\text { łem, Leonem } \\
\text { i Gabrielem }\end{array}$ & 1 & 1 & 10 \\
\hline 20 & 1 & $1 / 4$ & $1 / 4$ & $\begin{array}{l}\text { Anton Kozuszczyk } \\
\text { z bratem Konradem }\end{array}$ & $"$ & 1 & " \\
\hline 21 & 1 & $1 / 4$ & $1 / 4$ & \begin{tabular}{|l|} 
Leon Młynarz z \\
szwagrem Pawłem
\end{tabular} & $"$ & 1 & $"$ \\
\hline 22 & 3 & $1 / 4$ & $1 / 12$ & $\begin{array}{l}\text { Garbarzowa wdowa, } \\
\text { syny Jan, Tomasz } \\
\text { i Chwedor }\end{array}$ & $"$ & $"$ & $"$ \\
\hline 22 & 36 & $51 / 4$ & $31 / 2$ & Facit $^{30}$ & 3 & 16 & 21 \\
\hline
\end{tabular}

\section{[k. 8r] Powinność chłopów we wsi Storożowszczyznie mieszkających}

Z półwłoki ciągłej robić powinni z czym każą, chłopi trzy dni, a żonki trzy dni aż do Świętej Pokrowy ${ }^{37}$ a od Ś[więtej] Pokrowy do S[więtego] Jerzego, żonka dwa dni tylko, a chłop trzy dni. Gwałtu na rok dni osim. Jeden się tylko w domu dla ognia zostać winien, dziakła żyta szanek, owsa szanek, gotowych pieniędzy groszy dwadzieście pięć, kur dwoje, jajec dziesięć, talek lnianych dwie dawać co rok powinni, stróże odprawować do plebanii kolejno, inne powinności według dawnych inwentarzów pełnić powinni będą.

\begin{tabular}{|c|c|c|c|c|c|c|c|}
\hline Dymy & Syny & \multicolumn{2}{|c|}{ Włóki } & \multirow{2}{*}{$\begin{array}{c}\text { [k. 8v] Wies } \\
\text { Chodorki }\end{array}$} & \multirow{2}{*}{$\begin{array}{l}\text { Woły } \\
\text { sztuki }\end{array}$} & \multirow{2}{*}{$\begin{array}{l}\text { Konie } \\
\text { sztuki }\end{array}$} & \multirow{2}{*}{$\begin{array}{c}\text { Pszczoły } \\
\text { pnie }\end{array}$} \\
\hline osiadłe & osoby & osiadłe & $\begin{array}{l}\text { czynszo- } \\
\text { we }\end{array}$ & & & & \\
\hline 1 & , & $1 / 4$ & $1 / 4$ & Mikołaj Bielewicz & 2 & , & 40 \\
\hline 2 & 1 & $1 / 4$ & $1 / 4$ & $\begin{array}{l}\text { Wasil Nowik, } \\
\text { syn Janko }\end{array}$ & 2 & ", & ", \\
\hline 3 & 1 & $1 / 4$ & $1 / 4$ & $\begin{array}{l}\text { Dominik Siwy, } \\
\text { syn Tomasz }\end{array}$ & $"$ & $"$ & " \\
\hline 4 & 1 & $1 / 4$ & $1 / 4$ & $\begin{array}{l}\text { Ławryn Dobysz, } \\
\text { syn Janko }\end{array}$ & $"$ & ” & ” \\
\hline
\end{tabular}

${ }^{37}$ Pokrowa, Pokrow - święto Opieki Najświętszej Bogurodzicy lub Wstawiennictwa Bogurodzicy i Zawsze Dziewicy Maryi. Obchodzone w katolickich Kościołach wschodnich tradycji bizantyjskiej, w Kościołach prawosławnych, a także w greckim prawosławiu. Poświęcone opiece Bożej nad ludźmi za wstawiennictwem Maryi. 


\begin{tabular}{|c|c|c|c|c|c|c|c|}
\hline 5 & 1 & $1 / 4$ & $1 / 4$ & $\begin{array}{l}\text { Hryszko Kołot, } \\
\text { syn Mikołaj }\end{array}$ & $"$ & $"$ & " \\
\hline 6 & 3 & $1 / 4$ & $1 / 4$ & $\begin{array}{l}\text { Kuryło Kolesnik, } \\
\text { syny Niczypor, Leon } \\
\text { i Trochim }\end{array}$ & 1 & 2 & " \\
\hline 7 & 3 & $1 / 4$ & $1 / 4$ & $\begin{array}{l}\text { Kazimierz Kolesnik, } \\
\text { syny Mikołaj, Jurko } \\
\text { i Franciś }\end{array}$ & 1 & 2 & " \\
\hline 8 & 3 & $1 / 4$ & $1 / 4$ & $\begin{array}{l}\text { Tomasz Siwy, syny } \\
\text { Hryszko, Mateusz } \\
\text { i Jakim }\end{array}$ & 1 & " & " \\
\hline 9 & , & $1 / 4$ & $1 / 4$ & Michaś Kozuszczyk & 1 & , & , \\
\hline 10 & 4 & $1 / 4$ & $1 / 4$ & $\begin{array}{l}\text { Panas Kolesnik z } \\
\text { bratem Staśkiem, } \\
\text { syny Pietruś i Oleś }\end{array}$ & 2 & 1 & " \\
\hline 11 & 2 & $1 / 4$ & $1 / 4$ & $\begin{array}{l}\text { Benedys Świkło, } \\
\text { syny Józef i Piotr }\end{array}$ & 2 & $"$ & " \\
\hline 12 & 2 & $1 / 4$ & $1 / 4$ & $\begin{array}{l}\text { Michał Okowity, syn } \\
\text { Tomasz, wnuk Pietruś }\end{array}$ & 2 & 1 & " \\
\hline 13 & 4 & $1 / 4$ & $1 / 4$ & $\begin{array}{l}\text { Paweł Okowity, syny } \\
\text { Matwiej, Oleś, Janko } \\
\text { i synowiec Hryhor }\end{array}$ & 2 & 2 & " \\
\hline 14 & 1 & $1 / 4$ & $1 / 4$ & $\begin{array}{l}\text { Jasko Arabej, } \\
\text { synowiec Chwedor }\end{array}$ & 2 & $"$ & " \\
\hline 15 & 2 & $1 / 4$ & $1 / 4$ & $\begin{array}{l}\text { Francis Załoha, syny } \\
\text { Siemion i Marcin }\end{array}$ & 2 & $"$ & ", \\
\hline 16 & 4 & $1 / 4$ & $1 / 4$ & $\begin{array}{l}\text { Ławryn Świkło, } \\
\text { syny Janko i Mateusz, } \\
\text { wnuki Pawluk } \\
\text { i Pietruś }\end{array}$ & 2 & $"$ & " \\
\hline 17 & 2 & $1 / 4$ & $1 / 4$ & $\begin{array}{l}\text { Stefan Świkło, } \\
\text { syny Janko i Jaś }\end{array}$ & 2 & ” & " \\
\hline 18 & 3 & $1 / 4$ & $1 / 4$ & $\begin{array}{l}\text { Bazyl Choruzy, } \\
\text { syny Omelian, Stefan } \\
\text { i Paweł }\end{array}$ & 2 & $"$ & " \\
\hline 19 & 2 & $1 / 4$ & $1 / 4$ & $\begin{array}{l}\text { Ostap Kulhawy, syn } \\
\text { Janko, brat Maksim }\end{array}$ & 1 & ” & " \\
\hline 20 & 1 & $1 / 4$ & $1 / 4$ & $\begin{array}{l}\text { Siemion Arabej, } \\
\text { syn Janko }\end{array}$ & 1 & $"$ & " \\
\hline 20 & 40 & 5 & 5 & Facit & 28 & 8 & 40 \\
\hline
\end{tabular}

[k. 9r] Powinność wsi Chodorków taka, z czwierci ciągłej, z czym każą trzy dni gwałtu na rok dni osim, na które wszyscy mają wychodzić, jednego tylko dla ognia zostawić mają w domu, z każdej ćwierci ciągłej dziakła żyta pół szanka, owsa pół szanka, gotowych pieniędzy gr trzynaście, kurą jednę, jajec pięć, talka jedna, pszczoły wszyscy poddani mają na pół z dworem dzielić, stróże odprawować kolejno.

Benedykt Rumszewicz 
[k. 10r] Decretum visitationis seu reformationis penes Ecclesiam Kossoviensem relictum, et Anno D[omi]ni 1756, die 26 mensis Julii A[dmodum] R[everendo] D[omi]no Rumszewicz Parocho Kossoviensi intimatum

Ad bonum ordinem Ecclesiae Kossoviensis, cum non pauca desiderentur, illa omnia silentio praeterire visitationis munus non permittit, virtute cuius sequentia iniungimus puncta:

$1^{\text {mo }}$ Clausura ad s[anctum] fontem baptismi sine mora adstruenda, clavis vero ab eadem, uti et a ciborio in loco soli parocho seu commendario eiusdem Ecclesiae noto semper conservanda.

$2^{\mathrm{do}}$ Calices et missalia, quae reperatione indigent, cura adhibere celeriter $\mathrm{A}[\mathrm{d}-$ modum] R[everendo] $\mathrm{D}$ [omi] no Parocho commendavimus.

$\underline{3}^{\text {tio }}$ Corporalia nova facienda, albas et alia vestimenta frequentius lavanda, confessionale saltem unum construendum, pavimenta ecclesiae ex asseribus vel ex lateribus conficienda. Domum plebanalem novam aedificandam, alia vero aedificia vetera seu putrida deiicienda, ex eo, quod dictus A[dmodum] R[everendus] $\mathrm{D}$ [omi]nus Parochus habeat, unde ista omnia conficiat. Praesertim ex relicta pecunia antecessoris sui, quam in privatos usus suos salva conscientia sua expendere non possit.

4to Saepimentum circa caemeterium in spatio medii anni erigere, ipsumque caemeterium complanandum, arbores minores et arbusta, seu tribulos excisere et expurgare mandavimus.

$\underline{5}^{\text {to }}$ Ipsum A[dmodum] R[everendum] D[omi]num Parochum ne se ab Ecclesia absentare audeat, nisi in negotio eiusdem Ecclesiae, idque ad breve tempus, relicto certo in suo $[\mathbf{k} .10 \mathrm{v}]$ loco sacerdote serio admonuimus.

$\underline{6}^{\text {to }}$ Ex visitatione Personali, quoniam aliquae inconvenientiae patuerunt, quae occasionem scandali praebere possunt, ideo stricte A[dmodum] R[everendum] $\mathrm{D}$ [omi]num Parochum obligavimus ut in posterum intra cancellos modestiae et honestatis sacerdotalis se contineat, idque. sub paenis in S[ancti]s Canonibus praescriptis.

$\underline{7}^{\mathrm{mo}}$ Inventarium quod tempore visitationis male conscriptum praesentavit in spatio trium mensium meliori forma, ordine et charactere confectum sub paena suspensionis Vilnam comportare designavimus. Pro meliori autem praemissoriis robore et executione subscripimus.

Datum Kossoviae A[nno] D[omini] et mense ut supra. 
THE INVENTORY OF THE CHURCH AND PRESBYTERY IN KOSÓW OF 1751

\section{Summary}

The inventory coming from the Diocesan Archive of Drohiczyn is the detailed records of the state of the church and presbytery drawn up by the dean Rev. Krzysztof Modzelewski on 19 January 1751. The inventory was drawn up due to the fact that the parish in Kosów was taken over by Rev. Benedykt Rumszewicz. The former Polish borderland parish is now located within the borders of Belarus.

Keywords: the Polish Eastern Borderlands, the history of the Church, the history of the parish of Kosów 